\title{
GCLM Gene
}

National Cancer Institute

\section{Source}

National Cancer Institute. GCLM Gene. NCI Thesaurus. Code C38605.

This gene is involved in the detoxification of endogenous reactive oxygen species. It also plays a role in drug and xenobiotic metabolism. 